\title{
THE EFFECT OF TALENT MANAGEMENT ON EMPLOYEE PERFORMANCE WITH CORPORATE CULTURE AS A MEDIATING VARIABLE
}

\author{
Ilham Ananto Yuwono*), Arif Imam Suroso*)1, and Aida Vitayala Hubeis ${ }^{* *}$ \\ *) School of Business, IPB University \\ Jl. Raya Pajajaran, Bogor 16151 \\ ${ }^{* *}$ Department of Communication Science and Community Development, Faculty of Human Ecology, IPB University \\ Campus IPB Dramaga Bogor 16680
}

\begin{abstract}
Talent management is a dynamic and comprehensive process for developing the highest potential employees in an organization through direct and integrated development. To increase revenue and capabilities according to the company's portfolio in the telecommunications sector, especially in digital services, the company initiated a talent management program in the form of an internal corporate start-up program. The internal corporate start-up program is an initiative program that aims to capture and accelerate digital business innovation from employees. However, the evaluation process is still focused on the produced products' business aspects, not on the human resources aspect. Therefore, it is necessary to evaluate the relationship between talent management programs and the improvement of company human resources (especially aspects of corporate culture and employee performance). Corporate culture is an important factor because the internal corporate start-up program is one way to encourage a culture of innovation in the corporate environment. The samples used were saturated samples, in which the population was all employees who were members of the internal corporate start-up program, 55 employees located in Jakarta. The data processing and analysis method used was structural equation modeling-partial least square (SEM-PLS). SEM-PLS analysis results showed that corporate culture directly affected employee performance and acted as a mediating variable between talent management and employee performance.
\end{abstract}

Keywords: corporate culture, employee performance, human resources, SEM PLS, talent management

\begin{abstract}
Abstrak: Manajemen talenta adalah proses yang dinamis dan komprehensif untuk mengembangkan karyawan berpotensi tertinggi dalam suatu organisasi melalui pengembangan langsung dan terintegrasi. Dalam rangka meningkatkan pendapatan dan kapabilitas sesuai portofolio perusahaan di sektor telekomunikasi terutama di bidang layanan digital, perusahaan melakukan inisiasi program manajemen talenta dengan bentuk program internal corporate start-up. Program internal corporate star-upt merupakan program inisiatif di lingkungan perusahaan yang bertujuan menjaring dan mengakselerasi inovasi bisnis digital dari para karyawan. Namun hingga saat ini proses evaluasi yang dilakukan masih berfokus pada aspek bisnis dari produk yang dihasilkan, belum pada aspek sumber daya manusia. Oleh karena itu perlu dilakukan evaluasi mengenai keterkaitan antara program manajemen talenta terhadap peningkatan SDM perusahaan (terutama aspek budaya perusahaan dan kinerja karyawan). Budaya perusahaan merupakan faktor yang penting karena program internal corporate start-up menjadi salah satu cara mendorong budaya inovasi di lingkungan perusahaan. Pengumpulan sampel menggunakan sampel jenuh, di mana populasi dalam penelitian ini adalah semua karyawan yang tergabung dalam program internal corporate start-up dengan jumlah 55 karyawan serta berlokasi di Jakarta. Metode pengolahan dan analisis data dalam penelitian ini menggunakan analisis structural equation modeling - partial least square (SEM PLS). Hasil analisis SEM PLS menunjukkan bahwa budaya perusahaan, berpengaruh langsung terhadap kinerja karyawan maupun berperan sebagai variabel mediasi antara manajemen talenta dengan kinerja karyawan.
\end{abstract}

Kata kunci: budaya perusahaan, kinerja karyawan, sumber daya manusia, SEM PLS, manajemen talenta

${ }^{1}$ Corresponding author:

Email: arifimamsuroso@apps.ipb.ac.id 


\section{INTRODUCTION}

Employees are the heart and backbone of an organization. Thus, it is vital to hold the key to increasing employee potential because it keeps the organization on the right track. Talented employees are resources that drive organizations to achieve excellence and competitive and sustainable growth through optimal utilization of them (Meyers, 2016; Meyers and van Woerkom, 2014). As a result, talent management has received great attention in many organizations, by adopting different philosophies and strategies for managing talented employees.

Talent management practiced in organizations consists of several processes including attracting, developing, and retaining the talents of employees (Luna-Arocas, 2018). At the heart of talent management is the simple idea of identifying high potential employees, training them well and placing them in influential positions where they can best impact on organizational and employee performance (Collings et al. 2017).

There are many advantages to talent management, but there are still problems faced, including talent identification. Talent identification consist of assessments of individuals; employee's past, present and future value. Even though the assessment is safe, at the very least, this approach can be criticized for treating people only as a disposable resource (Painter-Morland et al. 2019). In modeling the relationship between talent management and other parameters, talent is seen as an individual property that can be measured based on the level of education, type of work and underlying skills (Florida and Mellander, 2018). Thunnissen and Gallardo-Gallardo (2017) believe that effective talent management has proven to be important to achieve the goals of the organization and demonstrate its competitive advantage, so that sustainable success is achieved by the organization.

Measurement of employee performance variables refers to Pradhan and Jena (2017) which consists of three dimensions, including task performance, adaptive performance and contextual performance. One that plays a role in influencing employee performance is employee welfare (Van De Voorde and Beijer, 2015). The practices of HR can benefit employee performance and on the other hand also have an effect on employee welfare. This finding indicates the possibility of a complex compromise pattern between HRM, employee welfare dimensions, and employee performance. Thus there are indications of trade-offs for these variables (Boxall et al. 2016). Organizations need to find the right balance between the use of rules and procedures to make employee performance predictable while giving employees the freedom to innovate spontaneously to adapt to challenges and changing situations (Fu et al. 2015; Muñoz-Pascual and Galende, 2017).

Organizational (corporate) culture in general can contribute in showing general values (Naranjo-Valencia et al. 2016), competitive advantage (Calciolari et al. 2018) accentuates employee behavior (Nazarian et al. 2017; Zhang and Li, 2016) and support for innovation (Kim and Chang, 2019). Kim and Chang (2019) found that adhocracy, clan and market culture types have a positive relationship with performance. Salimi and Aveh (2016) find that culture predicts performance in different cases, while Kraśnicka et al. (2018) found a positive relationship between organizational culture and employee performance in other companies as well. The type of organizational culture model consists of clan culture, adhocracy culture, hierarchical culture and market culture which can be used as a reference in the new model of cultural interaction (Rohim and Budhiasa, 2019)

In order to increase revenue and capabilities according to the company's portfolio in the telecommunications sector, especially in the field of digital services, the company initiated a talent management program in the form of an internal corporate start-up program. The internal corporate star-up program is an initiative program within the company that aims to capture and accelerate digital business innovation from employees. For companies and organizations, talent strategies also need to emerge to bridge the gap between the measurement of business aspects and HR aspects by means of a balanced integration between the two aspects (King and Vaiman, 2019; Meyers, 2016; Meyers and van Woerkom, 2014; O'Connor and Crowley-Henry, 2019).

According to Carroll et al. (2020), being responsible from stakeholders in terms of accountability, obligations, and organizational tasks in managing talent management, especially in this case, evaluating aspects of HR. Therefore it is necessary to evaluate the relationship between the talent management program and the improvement of the human resources. This study evaluates the influence of talent management program on corporate culture and the improvement of the employee performance. 
The purpose of this study is analyzing the condition of variables (talent management, corporate culture and employeeperformance), analyzing theinfluencebetween variables such as talent management, corporate culture, employee performance and analyzing the influence of corporate culture as a mediating variable between talent management and employee performance.

This study is limited to the scope of discussion regarding the influence between variables, including talent management, corporate culture and employee performance using SEM PLS analysis which is based on the personal perceptions of employees who are members of the internal corporate star-up program. The sample collection uses a saturated sample, in which the population in this study are all employees who are members of the internal corporate start-up program with a total of 55 employees located in Jakarta.

\section{METHOD}

The sample is part of the population whose characteristics are to be tested. The population in this study were all employees who are members of the internal corporate start-up program with active status and located in Jakarta, that totaling 55 employees. In this study, the sample size is 55 employees, so sample collection uses saturated sampling - nonprobability sampling. Saturated sampling is a sampling technique if all members of the population are used as samples.

Data collection methods used in this study are interview and questionnaire methods. Interviews are conducted when researchers want to conduct studies to find problems that must be examined, and if researchers want to know things from respondents in depth where the number of respondents is small. Questionnaires are conducted by giving a set of questions or written statements to the respondent to be answered.

This study uses data analysis methods with SEM PLS. SEM PLS is a very strong indeterminacy factor of analytical methods because for all data scales to be able to apply this method, the sample size does not have to be large and also does not require many assumptions (Ghozali, 2008). Measurement models are used for validity and reliability tests, while indicator models are used for causality tests (hypothesis testing with predictive models). The analytical method used is partial least square (Solimun et al. 2017). PLS is a general method used to estimate path models using latent variables and several indicators. The model in this study was built using one exogenous latent variable: talent management, and two endogenous latent variables: corporate culture and employee performance; and PLS is able to handle reflective and formative research models. This research model variable is reflective.

In a study conducted by Kim and Chang (2019) found that talent management has a significant positive effect on corporate culture. Especially for corporate culture variables related to innovation. Besides, finding from (Collings et al. 2017; Thunnissen and GallardoGallardo, 2017) also found that there is a strong positive between talent management and employee performance. Talent management can have the best impact on organizational and employee performance. Study from (Salimi and Aveh, 2016; Kraśnicka et al. 2018) on the other hand, have investigates the impact of corporate culture on employee performance. They found a positive relationship between organizational culture and employee (company) performance. Study from (Naranjo-Valencia et al. 2016; Nazarian et al. 2017; Zhang and Li, 2016) stated that corporate culture indirectly encourages talent management in improving employee performance in a company. From the literature above, the following hypothesis is proposed:

Hypothesis 1. Talent management is positively and significantly related to corporate culture.

Hypothesis 2. Talent management is positively and significantly related to employee performance.

Hypothesis 3. Corporate culture is positively and significantly related to employee performance.

Hypothesis 4. Corporate culture as a variable mediating talent management on employee performance.

This study uses data analysis methods with SEM PLS. SEM PLS analysis which is based on the personal perceptions of employees who are members of this program with the variables of talent management, corporate culture and employee performance. The outcome of this study is recommended managerial implication. Research framework in Figure 1.

\section{RESULTS}

\section{Characteristics of Respondents}

The respondents in this study were all employees in the program with active status and working locations in Jakarta. Respondents involved in this study were 55 
people, then all respondents were selected based on gender, status, band position, age, length of work and educational background.

Characteristics of respondents, the results seen from the characteristics of the sex in this study that the male sex was significantly greater than the respondents were female, meaning that the results showed that men dominated the number of employees in this program. This can be due to the aspect of work that requires greater allocation of time and energy when compared to routine work such as office administration. While on the status characteristics, the majority are married with a percentage reaching 72.7 percent.

Based on the characteristics of the position band, where the percentage is more evenly distributed from the position VI band to the position III band. Because this program was opened from the lowest level band level, namely position VI band to the middle position or managerial level band, band III.

While for the age characteristics, the majority of young age (under 30 years) is more dominant than old age and old age in the employees of this program with a percentage of young age of 70.9 percent, in this case there is a significant difference in the age characteristics. Because indeed from the work side, in this program requires a higher level of creativity and innovation, both aspects are needed in the development of new products. Where young employees are known to have a higher level of creativity and innovation, so they are more interested in joining this program.

Based on the length of time the respondent worked, there was a significant difference in the characteristics of the length of work where the age of the beginner level (working period less than 5 years) was more dominant in this program. Because according to the age characteristics which are dominated by employees with less than 30 years of age, so the majority of these employees are novice employees (working period of less than 5 years).

Furthermore, based on the last indicator of respondents in this study is that bachelor (S1) with a percentage of 81.8 percent and master (S2) with a percentage of 18.2 percent, meaning that bachelor (S1) dominate more employees in this program. This is because the average employee who enters this program is categorized as a novice employee who has not yet advanced to the master (S2) program.

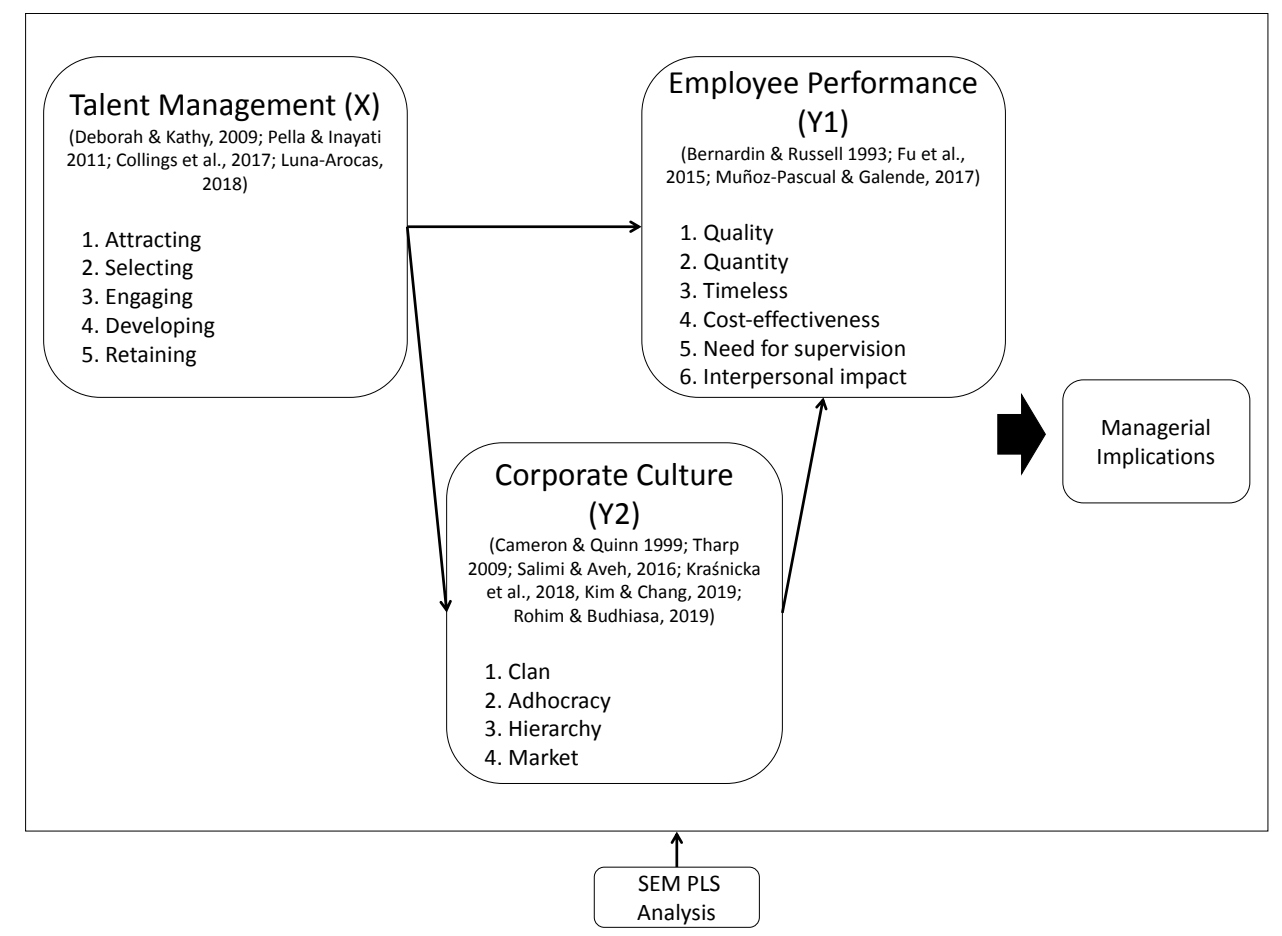

Figure 1. Research framework 


\section{Analysis Conditions Talent Management}

From Figure 2 can show the condition of each research variable. For talent management variables, there are three indicators with the highest mean value (close to 5) and have a loading factor $>0.5$ including opportunities for personal growth \& professional, personal responsibility and Innovation \& creativity. Because in this program, employees are given the freedom to develop or improve their abilities according to their needs, such as requesting training, certification or mentoring with experts. Personal responsibility or related to increased personal responsibility also has a high value, because in this program employees are given their responsibilities independently, starting from product development, budget management to marketing of the products produced. The highest value is in the aspects of innovation \& creativity, because in this program employees are given the freedom to innovate and exert creativity in product development in providing solutions to the market.

\section{Analysis Conditions Employee Performance}

From Figure 3 can show the employee performance variables, there are three indicators with the highest mean value (close to 5) and have a loading factor $>$ 0.5 , including ideas in decision making, employee engagement with the company and maximizing existing technology. Regarding ideas in decision making, where in this program employees are given flexibility in making decisions, starting from finding ideas, planning product development, until product marketing. The indicators of employee engagement with the company are considered good because indirectly the products or services developed as a team will make a direct contribution to the company, especially in increasing revenue and business process efficiency. Furthermore, for indicators of maximizing existing technology, in general this program contains employees with young backgrounds so that they can easily take advantage of existing technology to support their performance.

\section{Analysis Conditions Corporate Culture}

From Figure 4 can show the corporate culture variables can be grouped in three indicators with the highest mean (close to value 5) and have a loading factor value $>0.5$, namely discretion, dynamism, and flexibility which are categorized as adhocracy, where this type of culture is oriented to a very dynamic work environment, creative, innovative and risk-taking. This is in accordance with the environmental conditions of the internal corporate start-up program where this program encourages innovation, creativity and dynamic interaction, and is also supported by the composition of the majority of employees who are young.

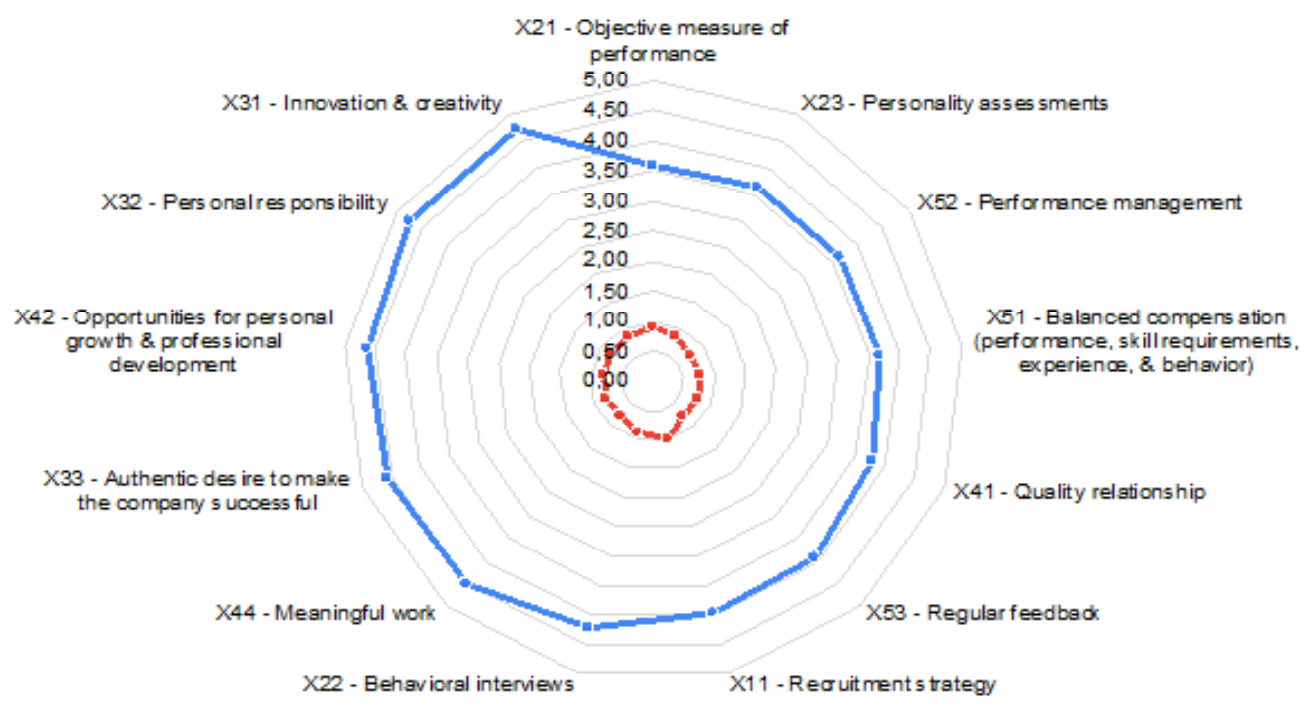

- Mean -_Outer logdings

Figure 2. Graph of talent management variable conditions 


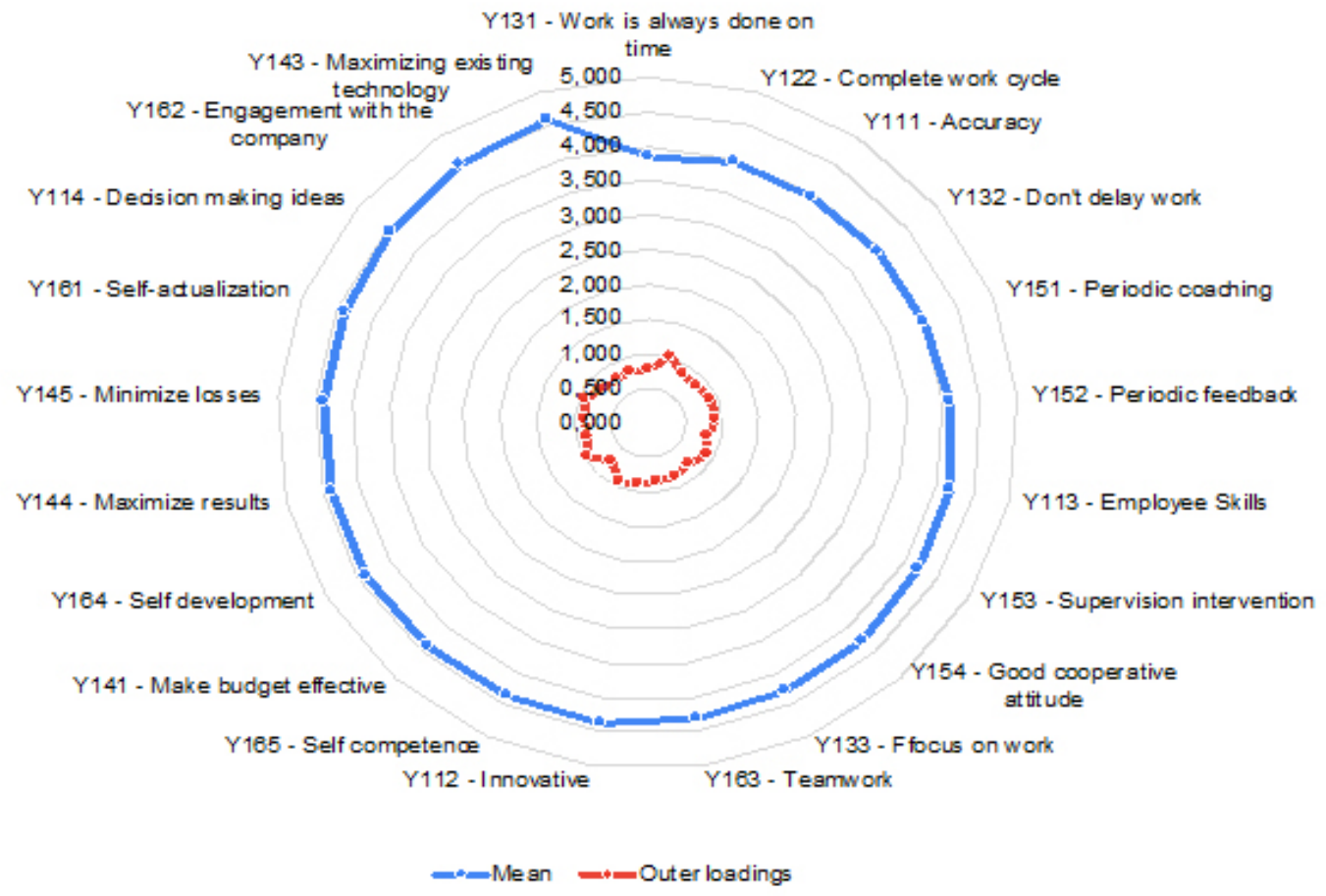

Figure 3. Graph of employee performance variable conditions

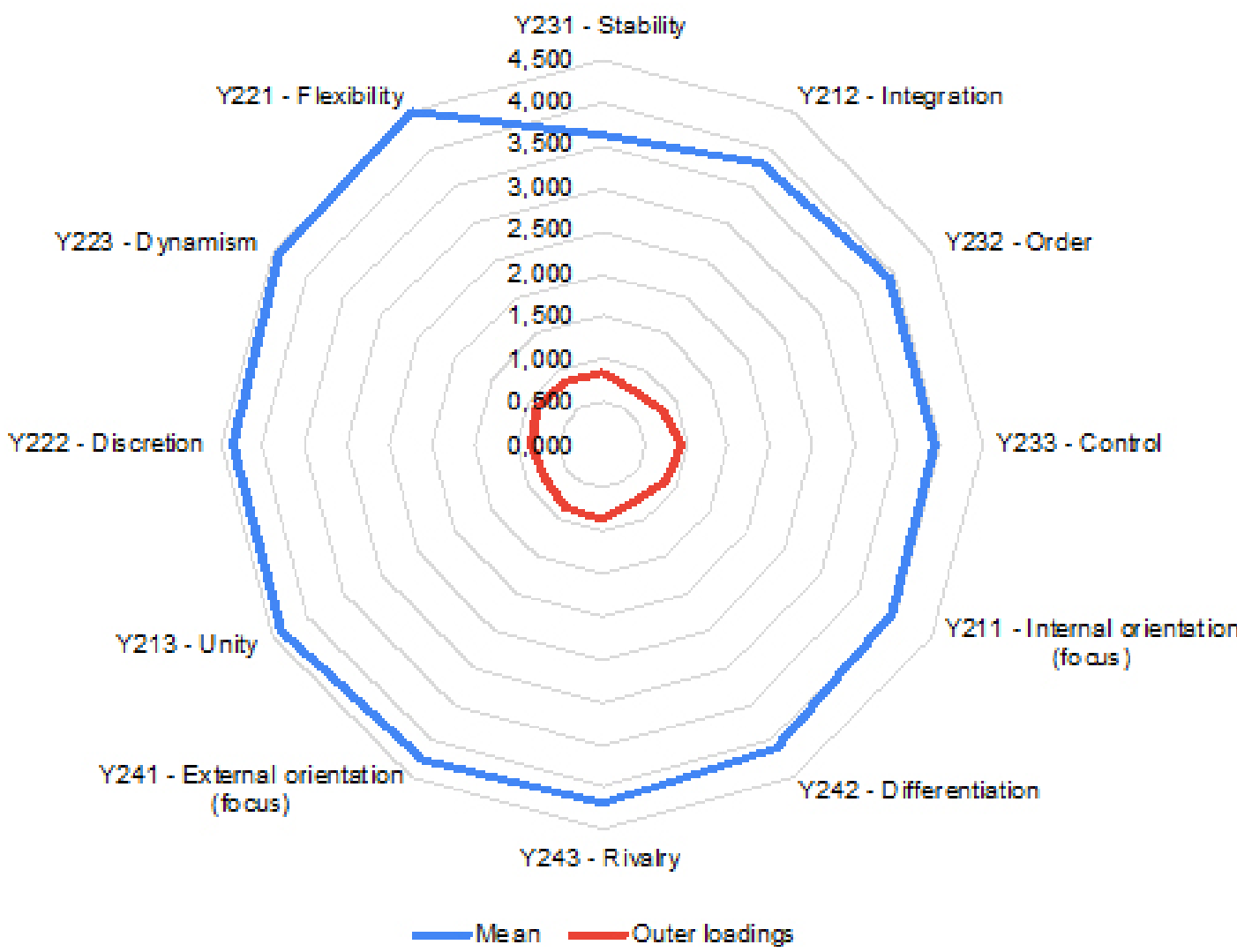

Figure 4. Graph of corporate culture variable conditions 


\section{Analysis of Relationships Between Variables}

Hypothesis testing based on path coefficients is done to see the relationship between research variables. Path coefficients are coefficients that indicate a significant level in hypothesis testing. The following are the hypotheses in this study are talent management is positively and significantly related to corporate culture. Talent management is also positively and significantly related to employee performance. Corporate culture is positively and significantly related to employee performance. The last, corporate culture as a variable mediating talent management on employee performance.

The hypothesis is accepted if it has a t-statistic value $>1.96$ and a significance level of p-value $<0.05$ (5\%). Below is presented a table of path coefficient results to answer the hypotheses proposed in this study. For complete test results are presented in Table 1 Path coefficient results. Hypothesis testing is done to answer the research objectives, to answer the hypothesis carried out bootstrapping techniques that are shown in the path coefficient results Table 1.

Talent management is positively and significantly related to corporate culture.

Based on the results of the path coefficient the t-statistic value for the relationship between talent management and corporate culture was 4,891 and p-value $<0.05(5 \%)$. This can be interpreted as rejecting $\mathrm{H}_{1}$, meaning that talent management has a significant effect. The results are consistent with the the research (Stans, 2012; Kim and Chang, 2019) which says that the development of good talent management will influence corporate culture in an organization.

Table 1. Path coefficient results

\begin{tabular}{lcccc}
\hline Latent Variable & $\begin{array}{c}\text { Original } \\
\text { Sample }(\mathrm{O})\end{array}$ & $\begin{array}{c}\text { T Statistics } \\
(|\mathrm{O} / \mathrm{STDEV}|)\end{array}$ & P Values & Annotation \\
\hline $\mathrm{X}$ - Talent Management $\rightarrow \mathrm{Y}$ 2 - Corporate Culture & 0.566 & $\left.4.891^{*}\right)$ & $\left.0.000^{*}\right)$ & $\begin{array}{c}\text { Reject H01/ } \\
\text { Significant }\end{array}$ \\
$\mathrm{X}$ - Talent Management $\rightarrow \mathrm{Y}$ 1 - Employee Performance & 0.112 & 0.619 & 0.539 & $\begin{array}{c}\text { Accept H02/ } \\
\text { Not Significant }\end{array}$ \\
$\mathrm{Y} 2$ - Corporate Culture $\rightarrow \mathrm{Y} 1$ - Employee Performance & 0.743 & $\left.5.350^{*}\right)$ & $\left.0.000^{*}\right)$ & $\begin{array}{c}\text { Reject H03/ } \\
\text { Significant } \\
\text { Reject H04/ } \\
\text { Significant }\end{array}$ \\
$\begin{array}{l}\mathrm{X} \text { - Talent Management } \rightarrow \mathrm{Y} \text { 2 - Corporate Culture } \rightarrow \mathrm{Y} 1 \text { - } \\
\text { Employee Performance }\end{array}$ & 0.421 & $\left.4.055^{*}\right)$ & $\left.0.000^{*}\right)$ & \\
\hline
\end{tabular}

*) t-statistic value $>1.96$ and $p$-value $<0.05(5 \%)$
Talent management is positively and significantly related to employee performance.

Based on the results of the t-statistic value for the relationship between talent management and employee performance was 0.619 and p-value $>0.05(5 \%)$, this can be interpreted as accepting $\mathrm{H}_{2}$. Therefore there is no significant effect between talent management on employee performance. These results indicate that the development of talent management still needs to be improved. This is consistent with Wahyuni's research (2019) which says that when talent management in a company still has obstacles, employee performance is not significantly influenced. In contrast to previous studies conducted by Mutiara et al. (2019) which states that talent management has a significant positive impact on employee performance variables.

Corporate culture is positively and significantly related to employee performance.

The $t$-statistic value for the relationship between corporate culture and employee performance was 5,350 and p-value $<0.05(5 \%)$, so this can be interpreted that reject $\mathrm{HO}_{3}$. Meaning that corporate culture has a significant effect on improving employee performance on talent management programs. The results of this study indicate that corporate culture has a significant and positive effect on employee performance. This is supported by research (Alharbi and Alyahya, 2013; Salimi and Aveh, 2016; Syafei at al. 2016; Kraśnicka et al. 2018) saying that a strong culture of the organization will help in increasing performance levels. 
Corporate culture as a variable mediating talent management on employee performance.

Based on the results of the path coefficient especially from indirect effects data, the t-statistic value for the relationship between talent management and employee performance through corporate culture is 4,055 and p-value $<0.05(5 \%)$, so this can be interpreted that reject $\mathrm{H}_{4}$.

These results are supported by the results testing of talent management significantly influencing corporate culture and the results testing of corporate culture have a significant effect on employee performance. But the results testing of talent management did not significantly influence employee performance. These results are included in the type of perfect mediation (Preacher \& Hayes, 2008). Perfect mediation means that the independent variable cannot significantly influence the dependent variable without going through mediation variables.

This research is supported by (Meng et al. 2016; Srihandayani and Kusnendi, 2020) saying that organizational culture can encourage the implementation of talent management that results in an increase in employee performance of a company or organization.

\section{Managerial Implications}

Talent management was increasingly recognized after the publication of The War for Talent by Chambers et al. (1998). Based on the results of the researchers' review that talent is scarce, therefore, only a handful of talented employees (Meyers, 2016; Meyers and van Woerkom, 2014), others argue that all employees have some special talents that can contribute to success in an organization or company (Cappelli and Keller, 2014; Gallardo-Gallardo et al. 2013; Meyers, 2016).

Human capital makes a difference in competitiveness and organizational success, the practice of human resources (HR) on employee performance has attracted much attention in the human resource management literature (Van De Voorde and Beijer, 2015). In this case, the proposed mediation model tells us that in order to achieve performance improvements, it requires the bonding of corporate culture from employees. Increased employee performance is likely to occur from the encouragement of corporate culture as a mediating factor, to achieve the goal of implementing talent management strategies. Perfect mediation type exists in this research model (Preacher \& Hayes, 2008), perfect mediation means that talent management variables cannot significantly influence employee performance variables without going through corporate culture mediation variables.

Based on the results of research that has been done, several priority factors are in line with the principles of talent management included in the development of HR (human resources), where talent management focuses on developing talent that has potential and competitive advantage that can advance the organization or company (Meyers , 2016; Meyers and van Woerkom, 2014).

Based on the research data, it can be concluded that to monitor the performance of employees requires the development of a performance management system, this system will function to monitor the development of the performance of the talents of the talents. The system should be able to monitor various aspects such as HR aspects, service business development aspects and budget use aspects. So that this system can be the initial foundation in the process of monitoring and evaluating each talent in this program (Jain, 2016). The development of the system can be done in stages based on the needs and results of validation with a variety of stakeholders such as employee representatives of program participants, management representatives, as well as representatives of program managers.

Furthermore, in relation to the application of corporate culture and performance improvement, talent management requires the implementation of personal assessment. The implementation of personal assessment is the best mechanism in recognizing the potential and constraints of each talent. This assessment process also cannot produce an instant or short-term improvement, because with a good assertion process, it will be found a suitable development path for each individual. So that in the long run, each individual can be mapped in detail in their development. Where this can also be harmonized with a performance monitoring system that has been built before. The personal assessment process can enrich the data in the performance management system. 


\section{CONCLUSIONS AND SUGGESTIONS}

\section{Conclusions}

The company initiated talent management program which is an internal corporate innovation program aimed at capturing and accelerating innovation from employees. The results of research where talent management has a significant influence on corporate culture so it can be concluded that the development of good talent management can support the creation of corporate culture implementation. Talent management does not significantly influence employee performance. This can occur because according to the assessment of respondents there are still obstacles from the implementation of talent management so that employee performance has not been able to improve properly. For corporate culture, it can be stated that it has a significant direct effect on employee performance. Corporate culture also acts as a mediating variable between talent management and employee performance. This means the culture of the company or organization can encourage the implementation of talent management that results in improved employee performance of a company or organization.

\section{Suggestions}

Suggestions that can be given and are expected to be useful for this company, especially is needed is the development of an appropriate talent management strategy because based on the results of research the influence of the existing talent management strategy has not maximally affected the improvement of employee performance. Managerial implementations that can be carried out such as the creation of a performance management system and the implementation of personal assessment.

From the research that has been done, it will be more interesting if the research is complemented in the future with other case studies from other sectors, because in this study the background is from the telecommunications sector where the company has a business focus there. However, some insights have been made in this study in answering some hypotheses that we hope can be supported by other researchers. In addition, more research is needed with mediating variables other than corporate culture that allow it to better understand employee performance improvement in relation to talent management, such as employee engagement, employee retention or employee satisfaction.

\section{REFERENCES}

Alharbi MA, Alyahya MS. 2018. Impact of organizational culture on employee performance. Prabandhan: Indian Journal of Management 11(6): 53-63. https://doi.org/10.17010/ pijom/2018/v11i6/128442.

Boxall P, Guthrie JP, Paauwe J. 2016. Editorial introduction: progressing our understanding of the mediating variables linking HRM, employee well-being and organisational performance. Human Resource Management Journal 26(2): 103-111.

Calciolari S, Prenestini A, Lega F. 2018. An organizational culture for all seasons? How cultural type dominance and strength influence different performance goals. Public Management Review 20(9): 1400-1422.

Cappelli P, Keller JR. 2014. Talent management: conceptual approaches and practical challenges. Annual Review of Organizational Psychology and Organizational Behavior 1(1): 305-331.

Carroll AB, Adler NJ, Mintzberg H, Cooren F, Suddaby R, Freeman RE, Laasch O. 2020. What 'are' responsible management? A conceptual potluck. (Eds). Edward Elgar, editor. Cheltenham: The Research Handbook of Responsible Management.

Chambers E, Foulon M, Handfield-Jones H, Hankin SM, Michaels EG. 1998. The war for talent. New York: The McKinsey Quarterly. 3: 44-57.

Collings DG, Cascio WF, Mellahi, K. 2017. Introduction in Collings, D.G., Mellahi, K. and Cascio, W.F. (Eds). London(UK): The Oxford Handbook of Talent Management, Oxford University Press, Oxford.

Florida R, Mellander C. 2018. Talent, skills and urban economies. London: The New Oxford Handbook of Economic Geography, Oxford University Press, Oxford, pp. 499-518.

Fu N, Flood P, Bosak J, Morris T, O’Regan P. 2015. How do high performance work systems influence organizational innovation in professional service firms?. Employee Relations 37(2): 209-231.

Gallardo-Gallardo E, Dries N, González-Cruz T. 2013. What is the meaning of 'talent' in the world of work?. Human Resource Management Review. 23(4): 290-300.

Ghozali I. 2008. Struktural Equation Modelling Metode Alternatif dengan Partial Least Square (PLS), Edisi Dua. Semarang: Badan Penerbit 
Universitas Diponegoro.

Jain S. 2016. Performance Management System: A Strategic Tool for Human Resource Management. New Delhi: Prabandhan Guru.

Kim T, Chang J. 2019. Organizational culture and performance: a macro-level longitudinal study. Leadership \& Organization Development Journal 40(1): 65-84.

King KA, Vaiman V. 2019. Enabling effective talent management through a macro-contingent approach: a framework for research and practice. BRQ Business Research Quarterly 22(3): 194206.

Kraśnicka T, Głód W, Wronka-Pośpiech M. 2018 Management innovation, pro-innovation organisational culture and enterprise performance: testing the mediation effect. Review of Managerial Science 12(3): 737-769.

Luna-Arocas R. 2018. Gesti_on del Talento. De los Recursos Humanos a la Direcci_on de Personas basada en el talent, (Talent Management. From Human Resources to People Management based on Talent). Madrid: Pir-amide Ed.

Meng, Fanxing, Xiaomei W, Huajiao C, Jin Z, Wei Y, Jin W, Quanquan Z. 2016. The influence of organizational culture on talent management: A case study of a real estate company. Journal of Chinese Human Resource Management 7 (2): 129-46. https://doi.org/10.1108/JCHRM-072016-0010

Meyers MC. 2016. Talent management: towards a more inclusive understanding. Tijdschrift Voor HRM 12(1): 1-12.

Meyers MC, van Woerkom MV. 2014. The influence of underlying philosophies on talent management: theory, implications for practice, and research agenda. Journal of World Business 49(2): 192203.

Muñoz-Pascual L, Galende J. 2017. The impact of knowledge and motivation management on creativity: employees of innovative Spanish companies. Employee Relations 39(5): 732-752.

Mutiara AN, Aida VH, Anggraini S. 2019. Talent management in improving the employees performance of PT PLN (Persero) TJBB APP Cawang. Indonesian Journal of Business and Entrepreneurship 5(1): 96-106. https://doi. org/10.17358/ijbe.5.1.96.

Naranjo-Valencia JC, Jiménez-JiménezD, Sanz-ValleR. 2016. Studying the links between organizational culture, innovation, and performance in Spanish companies. Revista Latinoamericana de Psicología 48(1): 30-41.

Nazarian A, Atkinson P, Foroudi P. 2017. Influence of national culture and balanced organizational culture on the hotel industry's performance. International Journal of Hospitality Management 63(2): 22-32.

O'Connor EP, Crowley-Henry M. 2019. Exploring the relationship between exclusive talent management, perceived organizational justice and employee engagement: bridging the literature. Journal of Business Ethics. 156(4): 903-917, doi: 10.1007/s10551-017-3543-1.

Painter-Morland M, Kirk S, Deslandes G, Tansley C. 2019. Talent management: the good, the bad and the possible. European Management Review.16(1): 135-146.

Pradhan RK, Jena LK. 2017. Employee performance at workplace: conceptual model and empirical validation. Business Perspectives and Research.5(1): 1-17.

Rohim A, IG Sujana Budhiasa. 2019. Organizational culture as moderator in the relationship between organizational reward on knowledge sharing and employee performance. Journal of Management Development 38(7): 538-60. https://doi. org/10.1108/JMD-07-2018-0190.

Salimi HA, Aveh MC. 2016. Relationship between organizational culture and innovation with the mediation of job enrichment in the Fars governor's staff. Indian Journal of Positive Psychology 7(1): 21-25.

Solimun, Fernandes AAR. 2017. Investigation the mediating variable: what is necessary? (Case study in management research), International Journal of Law and Management 59(6): 101110.

Srihandayani U, Kusnendi. 2020. Effect of talent management and organizational culture on the performance of employees (Study on Employee Brantas Abipraya Company, Jakarta). Proceedings of the 3rd Global Conference On Business, Management, and Entrepreneurship (GCBME 2018) 117(2018): 233-35. https://doi. org/10.2991/aebmr.k.200131.049.

Stans, Licica. 2012. Talent management and the cultural influences on human resource management processes a comparison on hrm practices between companies from Sweeden and Romania. School of Business, Economics and Law 19(81): 69.

Syafei M, Idqan F, Aida VH. 2016. Faktor-faktor 
yang memengaruhi kinerja karyawan $\mathrm{Pt} \mathrm{Pul}$ Logistics Indonesia. Jurnal Aplikasi Bisnis dan Manajemen 2(3): 217-29. https:/doi. org/10.17358/jabm.2.3.217.

Thunnissen M, Gallardo-Gallardo E. 2017. Talent Management in Practice: An Integrated and Dynamic Approach. New York: Emerald Publishing Limited.

Van De Voorde K, Beijer S. 2015. The role of employee HR attributions in the relationship between high-performance work systems and employee outcomes, Human Resource Management Journal 25(1): 62-78.

Wahyuni RA. 2019. Perceived organizational support dan talent management terhadap kinerja karyawan melalui employee engagement. Jurnal Ilmu Manajemen 7(4): 905-13.

Zhang X, Li B. 2016. Organizational culture and organizational performance: a brief review. Journal of Advances in Social Science and Humanities 2(5): 16-21. 